\title{
THE CHANGE FROM A COMMAND-TO A MARKET BANKING SYSTEM IN THE CASES OF SELECT GROUPS OF EUROPEAN COUNTRIES
}

\author{
Elena Stavrova ${ }^{1}$
}

\begin{abstract}
In this article, the general stages of the banking sector's transition to a free market are examined in the countries of Central and Eastern Europe and the effects of the last crisis on the financial and economic system of these countries. The process of this change is different and is important for their integration into the common European banking market, as well as their influence on the development of the economies of these countries as a whole. Therefore, the objectives of this study are to compare the processes of change in organizational structure and the difficulty of integrating these banking sectors with the banking sectors of Western European countries. The focus is also on assessing the impact of the global financial and economic crisis on their sustainable development. The databases of the World Bank and the International Monetary Fund have been used to establish a common pattern in some sectors - the growth of non-performing loans during the crisis, it also implies a concerted effort to overcome this important indicator of their sustainability and behavior.
\end{abstract}

JEL Classification Numbers: G15, F34, F36, DOI: 10.12955/cbup.v7.1379

Keywords: Post-crisis period, development of fin. companies, the banking sector's challenges in the crises.

\section{Introduction}

The comparative study of the banking sectors of former socialist countries has changed between 2007 and 2018. The public, the investment community, and the regulatory sector are watching significant quantitative and qualitative changes in this important sector of the economy. Privatization processes, foreign investment by Western European countries into the banking industry in these countries took place in different ways. As a result, competitive financial institutions have emerged offering state-ofthe-art customer service technologies providing significant benefits to investors. From state monopoly types, they have become systems in which almost all European banking systems are represented. The current crisis has led to a deterioration of core financial and credit aggregates to assess the quality of banking operations and the market position of financial intermediaries offering different types of financial intermediation. Structural changes, changes in the structure of supervision and control have limited regulatory arbitrage. Merger and acquisition and exit processes have caused significant changes in the financial landscape. Initially, large banks did not help their branches in Central and Eastern Europe, and later even split up with them, selling them to local investors. This process continued over time and fully reflects the processes of social and economic life as a whole. The banking industry, which is highly dynamic and innovative, has a very important position in the development of other sectors of the economic system because of the ability to transform resources and direct them to new and advanced technologies in economic areas. This is the way to ensure a high level of efficiency of incoming resources in the system. Our analysis includes the banking systems of Bulgaria, Hungary, the Czech Republic, Slovakia, Poland, and Romania, other CEE countries which are named later.

\section{Research questions}

The CEE countries experience a chronic shortage of resources and rely on foreign financing and credit growth. As with previous crises in other emerging markets, the penetration of these capitals takes place in several familiar ways. At what stage and for what other reasons, the banking sectors of these countries experience a tangible need for foreign financing? Factors that exert different pressure on rebalancing trends are analyzed, highlighting the possible unwanted consequences of the imbalance trends. These trends related to changes in the global regulatory agenda and policy measures are proposed to increase the supply of local stable sources of financing to banks and to increase the sustainability of banks. It is argued here the link between foreign ownership and foreign financing does not always have the same influence as the different areas changed the financing strategies of most big banks in Europe. The results of the complete restructuring of the banking sectors of the CEE countries will be assessed for a long time. The regulatory environment is undergoing rethinking to identify the potential for further impact on the European banking industry. Our aims have been to examine the sustainability and changes in the banking sector in the countries of the former socialist bloc and at a later stage - with the entry to the EU in the period of 2008-2018 by analyzing the data for six CEE countries, related to the banking sector and comparing their main categories and describing their situation.

\footnotetext{
${ }^{1}$ South-West University “Neofit Rilski”, Blagoevgrad, Bulgaria, stavrova@ @wu.bg
} 
The main research question we are aiming to answer is: are there any specific features of the way in which each analyzed banking sector has developed from 2008 to 2018 and are they currently performing better? The main purpose is to compare the main variable characteristics describing banking activities.

\section{Research methods and database}

To achieve the stated goal, we analyzed data collected from secondary sources (monetary authorities of the selected countries, the World Bank Group and the International Monetary Fund). The observed economic indicators are compared in advance. Here we followed the trend of developing internationally accepted assessments of the after crisis challenges as a level of credit activity and GDP; the dynamics of total loans and the sectorial structure of loans on non-financial corporations; the total amount of assets and GDP and the total assets; the non-performing loans in the total loan portfolio; the structure of ownership of the banking sector; deposits and deposit structures; and non-performing loans.

Literature sources including IMF study (2013), iASES (2019), Li (1999), and many others, who have set themselves the objective of assessing and analyzing the effects of changes in the structure, role and tasks of the banking industry.

\section{Evolution in the banking markets of Eastern Europe.}

Each of the analyzed countries in Eastern Europe followed a specific strategy during the selection of the route towards the development of their market principles of their banking industry. It turned out, that of the highest importance was the choice of economic system, namely its dependence on the demand and supply. Excepting that principle determined the speed and intensity of change in the banking industry. Some of the countries in Eastern Europe such as the Czech Republic, Poland and Hungary had the required time and ability to progress through every stage of change, while the slight lagging behind of Bulgaria resulted in the need of application of shock tactics. Despite sharing identical goals in their initial phase of the transfiguration of their banking sectors, their endeavors varied. The reasons for that were number of circumstances:

1. There were differences in the economic development and the process of democratization among the countries in Eastern Europe.

2. There were differences in the quality of development of their non-material culture: education and investment in social capital.

3. There was a difference in the liberalization of their economic systems.

4. Some of the countries had experienced already some more or less successful first steps towards transformation, which had turned out to be a significant impediment.

5. The important role played by the civic community in the changes, the acceptance or not of the reforms and the nostalgic feeling towards the Communist past.

6. Some of the countries followed the natural path towards change, while others organized it through their political systems.

Studying the events and changes in the countries of Eastern Europe could lead to the conclusion that their dissimilarities were based on their differences of social and economic developments. There could be identified two groups of countries, established on their success of their progress towards a market economy (their grant of membership into the EU in 2004): Poland, the Czech Republic, Hungary, Slovakia and Slovenia (last to join the group, but with a very dynamic economy). Despite the raising of few internal political disagreements among the institutions of the EU, those countries had inspired high hopes and proved the accuracy of their chosen paths towards prosperity. Following on their heels were Bulgaria and Rumania which joined the EU in 2007. The grant of membership was not a reward for successful completion of the process of transformation, but to act as a stimulus for its accomplishment. This was a factor which influenced and contributed to the progress of both countries. According to Svejnar (2002) and Li (1999) the former socialistic governments should have implemented various reforms in deconstruction of the inherited institutions such as: a new fiscal and monetary policy, direct control of the cost of labor and even fixed exchange currency. The reforms in the financial sphere should have included the creation and implementation of laws and another legal instrument and institutions. The fast developing changes had caused a disturbance and chaos during the privatization process of small and medium size businesses. The creation of effective, specialized and universal banks and the existence of appropriate regulatory infrastructure were of essential importance in turning Eastern Europe in an attractive target for foreign investment. 
According to Blanchard et al. (1997), and Kornai (1999) the analyzed Eastern European countries had achieved a remarkable range of different approaches to privatization in their banking sectors. Poland and Slovenia delayed the privatization of their state banks as they turned them into independent legal entities. Those financial groups had remained the property of the state and were governed by an independent overlooking administration. A wide opportunity was given for the creation of new private companies. Hungary effectively privatized all its banks by selling them to international investors. Despite the criticism towards this slow process, the method had demonstrated a number of advantages, the most important of which were the acquiring of managerial skills and the flow of investments into those privatized companies. This had helped generate their budget incomes and reap the results of better corporate management in the short period. Finally, in the Czech Republic and Slovakia the privatization was accomplished through the use of a voucher system and consequently the majority of companies remained in the hands of the population. This method could be judged as the fairest, but unfortunately did not generate new outside investments. Instead it led to widely dispersed ownership and an inadequate corporate management.

The privatization process of the financial sector in Bulgaria was done through a banking consolidating company, a holding company with a state majority ownership. Here was used the method mainly of "negotiations with a potential buyer", which contributed to the opaqueness of the deals, distorted pricing and caused many doubts in the fairness of the whole business. Some of the deals were signed using "debt against property" and in doing so the state repaid some of its foreign debt. This again contributed to unpleasant interpretations and worsening of the image of Bulgaria abroad.

According to Doltu (2000) the Rumanian Government chose to privatize its banking sector through using strategic investing. The common feature to all of the analyzed countries was their aim during the end of the 1980s to the beginning of 1990s to transform their economic system from central planning into a market economy, to part with Communism and build democratic state institutions. The processes of their change was expressed though the liberalization of prices, the free market, amended jurisdictions, strong encouragement for developing business, privatization, and embracement of a spirit of competition and reform in the banking industry management (Roaf et al., 2014). The challenges faced by the banking sectors of most of the countries in Eastern Europe were to complete these reforms before the start of the new millennium. In the Centralized Planned Economy of Bulgaria the central banks had functioned as trade holdings as well as central banks. Their role in this economic system visibly was administrative, it distributed budget resources and fulfilled government plans and decisions in restructuring and investing in different sectors (Miller and Petranov, 1993). The centralized banking system was abandoned and the banking industry moved towards a two-tier banking system, which meant the division of the functions of the central banks (emission banks) and other types of banks. Barisitz and Gardo (2009) identified two waves of bank reforms in system transition towards a market orientated system: a) Liberalization of the regulations of the banking market, identification of private banks who operated outside the law, which contributed to the worsening of banking actives and destabilization; b) Second wave of privatizations of banks by foreign companies. The results of the reforms in the banking sectors of the countries in Eastern Europe were: growth in the banking services through the development of their institutions and branches (Table 1); introduction of investment capital with know-how, credit expansion in 2005-2006 (especially in the sector of households loans; increase of the share in risk actives and currency exposures, improvement of the efficacy of bank's operations; development of an international framework for bank supervision such as the Basel Agreement; and improvement of the international auditing standards and discipline and transparency.

\begin{tabular}{|c|c|c|c|c|c|c|c|}
\hline $\begin{array}{l}\text { № } \\
\end{array}$ & Country & Operating & Closed & $\begin{array}{l}\text { Commercial } \\
\text { banks }\end{array}$ & $\begin{array}{l}\text { Branches of } \\
\text { foreign banks }\end{array}$ & $\begin{array}{l}\text { Savings } \\
\text { Bank }\end{array}$ & $\begin{array}{l}\text { Cooperative } \\
\text { banks }\end{array}$ \\
\hline 1. & Bulgaria & 27 & 6 & 20 & 6 & - & - \\
\hline 2. & Hungary & 73 & 126 & 24 & - & 34 & - \\
\hline 3. & Slovakia & 29 & 4 & 9 & 16 & - & - \\
\hline 4. & Poland & 645 & 63 & 38 & - & - & 548 \\
\hline 5. & Romania & 38 & 9 & 26 & 9 & - & - \\
\hline 6. & The Czech Republic & 63 & 7 & 18 & 28 & - & - \\
\hline
\end{tabular}


The influx of investment resources into the banking sector contributed to the import of new banking technologies, improvement in the banking services, and development and marketing of individual banking products according to the needs of the client. The new owners implemented more responsible methods of bank governing which limited their risks.

\section{Banking sectors in Eastern Europe during and after the global financial crises}

The global financial and economic crises changed the conditions in the financial systems. For the banks in the region the period before the crises was marked with fast and positive growth. The integration with economies of Western European countries was an important factor in their economic growth. With time the influence of private consumption formulated significant differences up until 2008 in the development in the countries of Eastern Europe (Gardo and Martin, 2010). In regard to Romania, there was a negative impact on the fixed exchange currency. Through instruments of monetary policy this monetary administration encouraged an increase of capital and financial credit (IMF, 2011). Albulescu (2011) considered the financial and economic integration from the beginning of the 2000s in countries in Eastern Europe of great importance. The aims towards financial stability and the supporting of the process of integration were seen as crucial to the economic development and employment. The periods of instability had an impact on all participants in the market disregarding their type of industry or market share. The integration into the European trade and banking market of the analyzed countries of Eastern Europe played a great determining role. A number of investigations by different authors have measured the economic integration through a variety of tools: foreign actives as a share of the banks' actives, unsecured loans as a share of the overall credit, interest on the consumer credit, and most importantly, the measurement of the level of financial integration through the foreign banks share in the overall sum of actives. The process of integration with the Western financial infrastructure was important for the acquirement of Western practices of risk management curbing the opportunities of development and spread of financial calamity. According to Pagano (1993), the process of integration of the countries in Eastern Europe has confirmed the existence of three channels for the introduction of financial development and influence over the economic growth: 1 . The access to the financial system was improved through the decrease of the expenditure on financial brokerage and bank's debts were transformed into the bank's investments with minimal transaction expenditure. Figure 1 demonstrates the dynamics of the deposit base in the banks of the analyzed countries. This growth turned out to represent a proof of the increased confidence between brokers and investors. 2. The effective financial sector had attracted increased resources for investment and distribution. 3. The economic growth had influenced the growth in savings in the systems. 4. The process of financial integration has improved the access of each side to credit resources on the international markets through savings from investments. (Gianetti et al., 2002, p.14). The dynamics of the deposits measured as a share of GDP is important evidence which shows the reserves of the financial system. It stems from the type of taxation system whether in income growth or consumer taxing. It needs to be taken into account that marginal savings rates are very dynamic during crises time. The researched period is strongly connected with the crises in the European economy when the public, in an attempt to protect the devaluation of their national currencies and to possess liquidity, had in reality acted according to Keynes' "savings paradox". Another factor contributing to the affinity to savings was also the age of the population. As a result, the high credit demand was funded by inflows, especially in 2007 in countries with fixed exchange rates. The regime encourages higher capital inflows and currency credit for various reasons (IMF, 2011), for example the monetary policy. At the same time, banks' demand for currency liabilities was growing. Albulescu (2011) assesses the economic and financial integration in the early 2000s of CEE countries as important. Ensuring financial stability, achieving, facilitating and encouraging the integration process is important in promoting employment and economic development. The periods of instability affected all market participants. Several indicators for measuring economic integration were used: Foreign assets as a share of the total assets of banks; non-performing loans as a share of the total loans, and consumer Interest Rates. In addition, the share of Foreign Bank Assets were used to highlight the extent of financial integration. The financial system integration into a Western financial infrastructure is of particular importance for the process of cohesion development of post-socialist banking systems.

The first effect is to improve the efficiency of the activity of financial intermediaries and the markets of less developed countries by facilitating the penetration of foreign investors. Foreign institutions can acquire stakes in banks or the banks entirely. Increased competition has an impact on the overall market 
situation because other participants have to limit their costs and improve the quality of bank products. Second, as a rule, financial integration improves the quality of banking supervision, which should be in line with best practices in the integrated area to ensure an "equal field" (Milanova, 2012) and to help curb unfavorable choices caused by inadequate regulation. According to Pagano (1993), the challenging processes in CEE countries confirms three main channels for financial development, transmission and influence on economic growth: enhancing the access to the financial system by reducing the cost of financial intermediation and turning bank liabilities into bank investment with the smallest transaction costs.

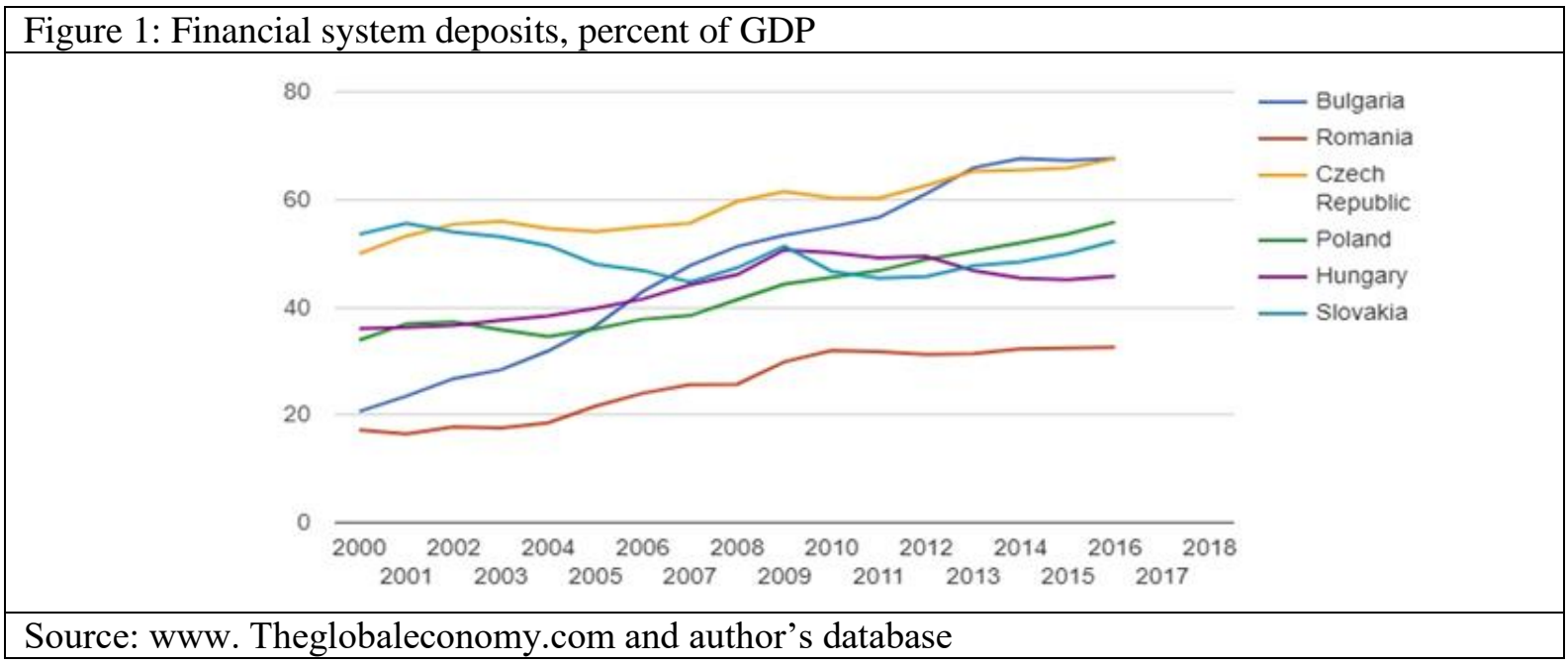

The dynamics of deposits, measured as the share of deposits as part of the GDP, is an important indicator showing the reserves of a financial system. This indicator is important because it is a magnitude resulting from the type of tax system - whether it is income or based on consumer taxes. The "marginal saving potential", which is very dynamic in times of crisis, must also be taken into account. The stage we are exploring is closely linked to the crisis situation of the European economy when the population, in order to protect against the devaluation of national currencies, and to ensure liquidity, realizes the so-called John Maynard Keynes' Savings Paradox. Another factor that determines the marginal propensity of savings is the age structure of the population. In those of the analyzed countries with stable birth rates and unchanged median age the tendency for marginal savings had not changed considerably. According to Trifonova, S. (2005) Bulgaria with its rapid decrease in population had a growth in financial deposits because of the tendency towards savings by the public in their different life stages. The low level of savings in Romania was caused by the increase of taxation and the exit of companies from the grey economy according Z. Marian and Bauble A., Balacescu An (2015). The economy had caused a decrease of the income amount as a basis for taxation and was also an effective method for attracting investments. The Romanian analysts had argued that inadequacy between the tax system and the impetus of economic development had assured a negative impact on the future prosperity of the country. Poland, which had comparatively low levels of savings, experienced growth in the period of the crisis of 2011 with a sharp increase of savings from the nonfinancial sector. Al Kolasa and B. Libdera (2014) have established that this change was a result of the increase of corporate nonfinancial savings. Brut household savings, containing net capital increase in pension funds, decreased since 2001 as well as the GDP. Their share decreased to $6 \%$ from the overall brut savings of the economy during 2011. Free choice household savings, without an increase of net capital mainly in the state pension funds, has decreased even more: up to 5\% of all savings in the period 2001-2011. Figure № 2 demonstrates the change in real GDP for the period after 2000, a clear evidence for the considerable downfall experienced by all of those six countries in the period 2007-2011. The diagram shows the shared tendency by all of sharp falls in GDP for 2008. The quick recovery of their national economies unfortunately did not reach pre-crises levels. Despite them all being outside of the Euro currency zone, their high levels of integration had a negative impact on them and the crises that had enveloped all European economies. The central banks were compelled to use non-traditional methods for overcoming the recession after the economic crises of 2008, while interest rates were negative in the long term. These tendencies had decreased the interest rate of debt in the private sector in an attempt to relieve their servicing. This was one of the main 
mechanisms for stimulating the economic activity in the time of crises, namely through an offer of cheap credit by banks taking part in a competition for financing good projects. St. Simeonov (2018) argues that the interest rates had decreased the cost of servicing the national debt, which also turned out in support of public finance stability. Low interests on credit transactions were a result of low interests on deposits. This dependency influenced directly the bank returns, which were compelled to turn to other profit sources. Another effect was the deposits collected were guaranteed the required return after being invested in the banks and invested in their main type of operations - credit operations.

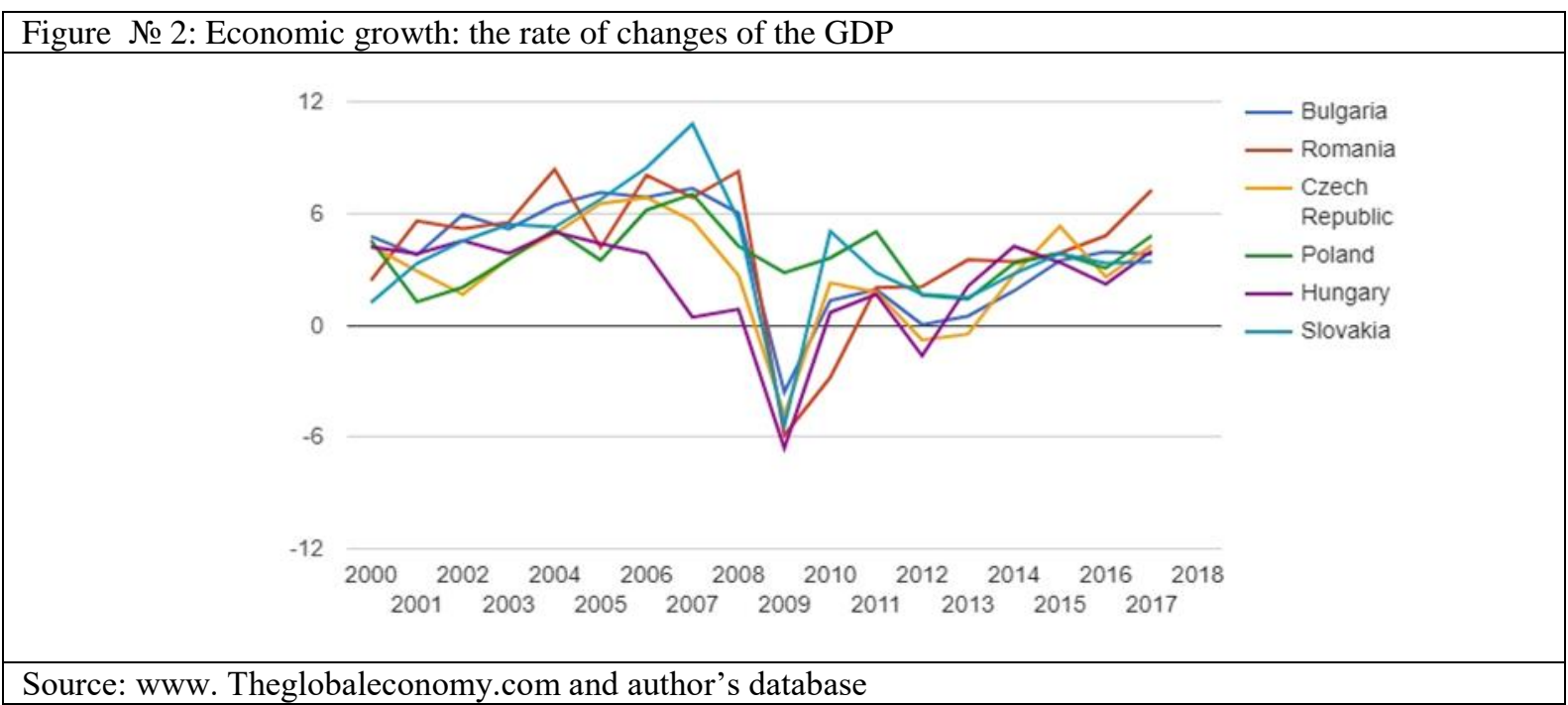

The unavoidable outcome of the crises in the banking sectors of the analyzed countries was the increase of the nonperforming loans and loans with delayed payment. Figure № 3 demonstrates the dynamics of the period from the onset of the crises up to present day. A fourfold increase in these types of credit in Rumania, Bulgaria and Hungary, a clear fall and a later reach of pre-crises levels.

The trend in Slovakia, the Czech Republic and Poland where the crises had only a symbolic impact was considerately different. It was reflected in an increased overall of $1.5 \%$ to $2 \%$ of problematic debt. The low interest on credit transactions and the low interest on deposits directly influenced bank returns, driving them to search for other income sources.

From all of the analyzed countries only Slovakia was part of the Euro monetary zone and the rest: Bulgaria, Hungary, Rumania, Poland and the Czech Republic were only members of ERM-II. The Czech Republic had fulfilled the criteria of the ECB with greater success. The forecast is the acceptance of the Euro currency in the next decade (Euro Commission, 2014).

\section{Conclusions}

The banking sectors of the countries in Eastern Europe had to experience great transformations in order to become full members of the European banking family. There were a variety and some of challenging paths undertaken by them, resulting in a venture into a highly competitive sphere of high technological level banking, artificial intelligence and global value chains. Each of those sectors suffered on a different level from the impact of the Global financial crises. The analyzed countries shared much in their experience: their chosen direction of progress through changes in the ownership and also harnessing of national policy for future expansion in their banking sectors. Closely connected to their progress was their growth in GDP and the PPP of their national currency. The response of the GDP has been remarkable as a variable for assessing economic activity during the global financial and economic crisis. All of the countries had shown decline in its onset, followed by a rapid recovery to previous levels. The greatest differences were discovered in the study of the dynamic levels of non-performed loans. This was an impact caused by policies of the Central Bank and by a secondary effect of the fluctuations of economic development.

The level of non-performing loans warranted attention, because of the difficulty and tardiness with which it returned to pre-crises level. It is especially salient in the case of Bulgaria, because the financial system functioned during the implementation of currency board with reserve currency Euro with fixed exchange rate to Bulgarian lev. There the key criteria was stability for its successful operation. 


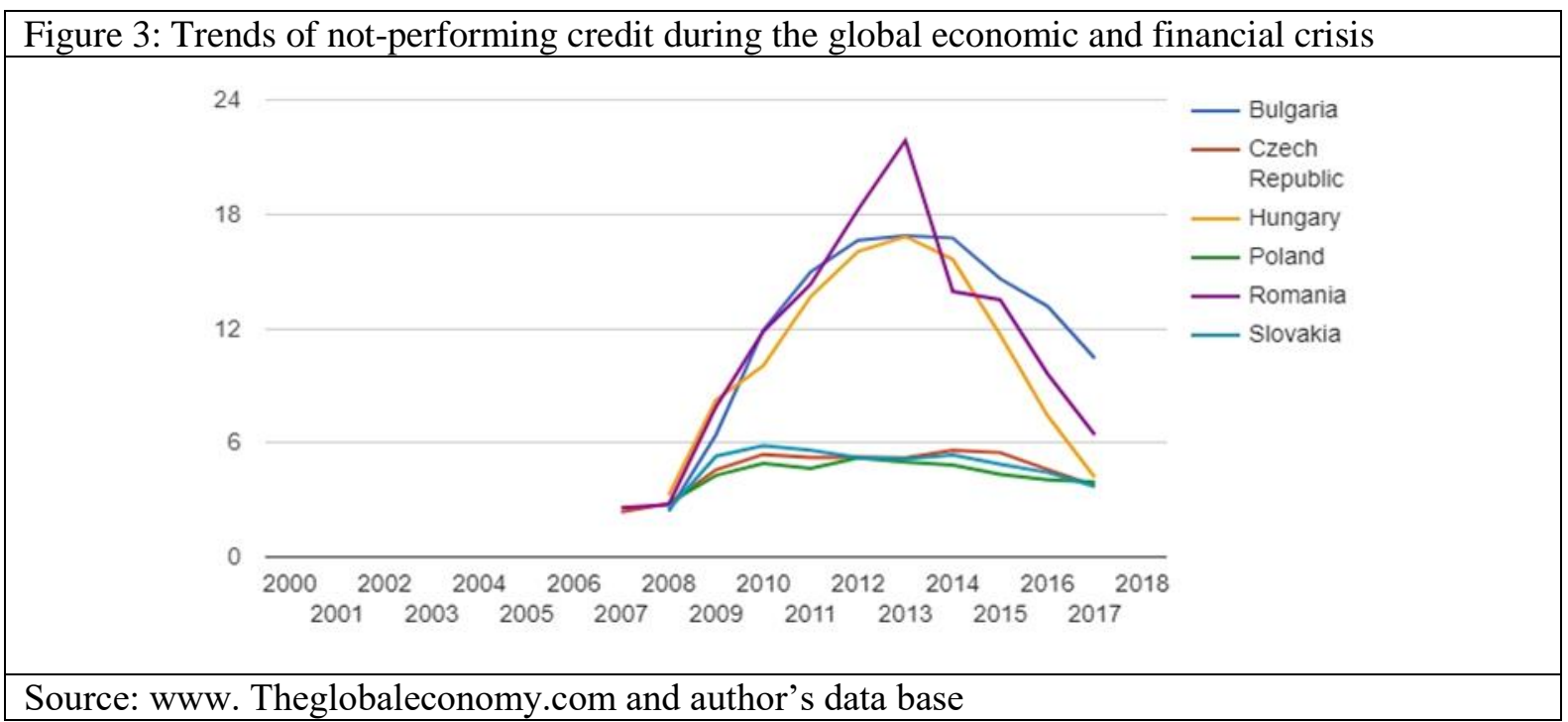

The market 'fluctuations were indicatives for internal misbalance, which was the cause for the accumulation of non-performing loans in the system. Those conclusions could be used as an advice for central banks of countries affected by a crisis in their banking sectors. It recommends the taking of necessary political measures to decrease levels of non-performing loans and therefore to reduce the financial stability.

\section{References}

Al. Kolasa, Al., B. Liberda. (2014). "Determinants of saving in Poland: Are they different than in other OECD countries?," Working Papers 2014-13, Faculty of Economic Sciences, University of Warsaw.

Barisitz\&Gardo (2009). "Banking Sector Transformation in CESEE”. ocus on European Economic Integration Spec. issue Blanchard, Ol. J. and M. Kremer. (1997) “Disorganization.” Quarterly Journal of Economics. 112:4, pp. 1091-126.

Claudio T. , Albulescu (2011). „Economic and Financial Integration of CEECs: The Impact of Financial Instability“. AUCO Czech Economic Review 5 (2011) 27-45. Acta Universities Carolinae Oeconomica.

Doltu, C.(2000). “The evolution of banking system in Romania”. RCEP/WP no.8/October 2000.

European Commission (2014). European Financial Stability and Integration Report 2013.

Gardo, S., and Martin, R.(2010) The Impact of the Global Economic and Financial Crisis on Central, Eastern and SouthEastern Europe: A Stock-Taking Exercise (June 17, 2010). ECB Occasional Paper No. 114. Available at SSRN: https://ssrn.com/abstract.1626117

Giannetti, M. and St. Onega. (2005). Financial integrating and entrepreneurial activity evidence from foreign bank entry in emerging markets, WP NO. 498 / JUNE, 2005

IASES. (2019). The imperative of sustainability. Economic, social, environmental. http://www.iags-project.org.

IMF (2011). "Capital Inflows, Exchange Rate Flexibility, and Credit Booms”. WP/12/41.

IMF. (2013). "Bank Funding in Central, Eastern and South Eastern Europe Post Lehman: a "New

Kornai, J. (1999). "Reforming the Welfare State in Post socialist Economies," in when is Transition Over? Annette Brown, ed. Kalamazoo, Mich.: W.E. Upjohn Institute for Employment Research, chapter 6.

Li, W.(1999). “A Tale of Two Reforms.” RAND Journal of Economics. 30:1, pp. 120-36.

Marian, Z., B. A., Bălăcescu An. (2015)."Dynamics and Their Determinants in Household Deposits in Lei. Case of Romania after the Financial Crisis". Annals - Economy Series, Constantin Brancusi University, Faculty of Economics, vol. 6, pages 237-240, December.

Milanova, E. (2012). "The new philosophy of the Basel-3, Department "Accountancy and Analysis". University of National and World Economy.

Miller, J., St Petranov. (1993). The banking system in Bulgaria. Normal”? WP/13/148.

Pagano, M. (1993) «Financial Markets and Growth: An Overview », European Economic Review, n 37, p 613-622.

Roaf, J.q R. Atoyan, B. Joshi, Kr. Krogulski. (2013). 25 Years of Transition Post-Communist Europe and the IMF. ISBN: 978-1-49834-201-8.

Svejnar, J. (2002). “Transition Economies: Performance and Challenges”. Journal of Economic Perspectives—Volume 16, Number 1-winter 2002-Pages 3-28.

Simeonov, St., S. Zarkova, A. Peneva. (2018) Dependences between government debt and investment activities. Parallel analysis of the Bulgaria and Greece processes. Science researches, № 26/2018, pp 110-154. 